\title{
Aggregation of Sodium Channels during Development and Maturation of the Neuromuscular Junction
}

\author{
M. T. Lupa, D. M. Krzemien, K. L. Schaller, and J. H. Caldwell \\ Departments of Cellular and Structural Biology and Physiology and the Neuroscience Program, University of Colorado \\ Health Science Center, Denver, Colorado 80262
}

\begin{abstract}
The voltage-activated $\mathrm{Na}$ channel ( $\mathrm{NaCh}$ ) is an integral membrane protein that is enriched at the neuromuscular end plate. Using loose-patch voltage-clamp and immunofluorescence, we have found that the aggregation of NaChs occurs late, during maturation of the neuromuscular junction. A decline in expression of embryonic NaCh mRNA and increase in adult NaCh mRNA precedes the onset of aggregation, and the appearance of functional adult $\mathrm{NaCh}$ coincides with $\mathrm{NaCh}$ aggregation. We tested the possibility that only the adult NaCh subtype could aggregate during development and found that both the embryonic and adult isoforms become concentrated at the synapse. The $\mathrm{NaCh}$ is the first postsynaptic membrane protein shown to become clustered postnatally, and the mechanism producing this aggregation appears to be different from the process producing aggregation of other synaptic proteins.
\end{abstract}

IKey words: neuromuscular junction, $\mathrm{Na}$ channel, tetrodotoxin, endplate, loose patch clamp, RNase protection, postnatal development]

The development of the neuromuscular junction is a dynamic process that progresses through several stages marked by specific events (for reviews, see Salpeter and Loring, 1985; Bloch, 1989; Salpeter et al., 1992). The earliest stage is initiation of synaptogenesis. The first indication of synapse formation in embryonic muscle, occurring about embryonic day 14 in rodents (Bevan and Steinbach, 1977; Lupa and Hall, 1989), is the aggregation of $A C h$ receptors (AChRs) and several other proteins in the vicinity of the neurite and growth cone (Anderson and Cohen, 1977; Froehner, 1991). During the next stage of synaptic development the pre- and postsynaptic elements become more precisely aligned, probably mediated by a distinct synaptic basal lamina that appears at this time (Chiu and Sanes, 1984). The nerve terminal and postsynaptic structure expand and AChRs become metabolically stable. The final stage involves the postnatal maturation of the neuromuscular junction and includes

\footnotetext{
Received May 13, 1992; revised Aug. 21, 1992; accepted Oct. 1, 1992.

We thank Drs. A. Ribera and G. Owens for inexhaustible help with the RNase protection assay. We also thank Drs. R. Barchi and $S$. Cohen for contributing the $\mathrm{NaCh}$ mAbs. Dr. S. Thesleff cleverly suggested the use of the "ear-waggler" muscle to us and offered constructive criticism of the minuscript. Dr. J. Clayton helped with the imaging of autoradiographs. We thank Drs. W. Betz and B. Wallace for helpful criticism of the manuscript. This work was supported by grants from the NSF (BNS 8809182) and the NIH (NS 26505).

Correspondence should be addressed to J. H. Caldwell, University of Colorado Health Science Center, Department of Cellular and Structural Biology, 4200 East 9 th Avenue, B-1 11, Denver, CO 80262.

Copyright (c) 1993 Society for Neuroscience $0270-6474 / 93 / 131326-11 \$ 05.00 / 0$
}

numerous changes on both a cellular and a molecular level: AChR subunits and channel kinetics change (Sakmann and Brenner, 1978; Mishina et al., 1986; Gu and Hall, 1988), synaptic vesicle proteins are restricted to the nerve terminal (Lupa and Hall, 1989; Dahm and Landmesser, 1991), subsynaptic folds appear (Terävainen, 1968; Kelly and Zacks, 1969), and polyneuronal innervation is eliminated (Betz et al., 1990).

Much is known about events that take place during the initiation of synaptogenesis. In fact, the mechanism behind the clustering of AChRs on myotubes is the best-understood process in postsynaptic differentiation. The basal lamina protein agrin is believed to play a primary role in this process (Magill-Solc and McMahan, 1988; Fallon and Gelfman, 1989; Wallace, 1989) by inducing phosphorylation of laterally diffusing AChRs at sites of agrin deposition (Wallace et al., 1991). Agrin also induces aggregation of several extracellular matrix and cytoskeletal proteins (Wallace, 1989; Nitkin and Rothschild, 1990). In contrast to the initiation of synaptogenesis, little is known about mechanisms regulating stabilization and maturation of the neuromuscular junction.

The voltage-activated $\mathrm{Na}$ channel $(\mathrm{NaCh})$ is an integral membrane protein that is necessary for the conduction of action potentials in the muscle cell membrane. Electrophysiological (Thesleff et al., 1974; Betz et al., 1984; Beam et al., 1985) and immunocytochemical (Haimovich et al., 1987) studies have shown that this protein is highly enriched at the neuromuscular junction. Electron microscopy has revealed that the $\mathrm{NaCh}$ and AChR exhibit nearly complementary distributions at the synapse, with AChRs confined mainly to the crests of the postsynaptic folds and $\mathrm{NaChs}$ lining the postsynaptic troughs (Flucher and Daniels, 1989). Little is known about changes in $\mathrm{NaCh}$ distribution during development. One study has reported that $\mathrm{NaChs}$ became clustered at sites of neurite-associated AChR clusters on chick myotubes in vitro (Angelides, 1986); this suggested that the processes of $\mathrm{AChR}$ and $\mathrm{NaCh}$ clustering might be similar or closely linked. However, recent experiments showed that although the basal lamina protein agrin had a dramatic effect upon AChR distribution, it had little effect on the distribution of NaChs on cultured muscle cells (Lupa and Caldwell, 1991). These results raised the possibility that the processes regulating the distributions of $\mathrm{AChRs}$ and $\mathrm{NaCh}$ s were separate and different. In order to gain insight into the mechanism producing the concentration of $\mathrm{NaCh}$ at the end plate, we have used patch-clamp recording and immunofluorescence to follow the process of $\mathrm{NaCh}$ aggregation in developing muscles. For this purpose we adapted a thin mammalian muscle preparation for use in loose-patch voltage-clamp experiments. We found that $\mathrm{NaChs}$ did not become concentrated at rodent synapses until 
1-2 weeks after birth. In fact, $\mathrm{NaCh}$ aggregation appeared to be one of the latest aspects of maturation at this synapse.

A change in ion channel subtypes also occurs during synapse maturation. The main type of $\mathrm{NaCh}$ expressed in adult innervated muscle has a single-channel conductance of about $15 \mathrm{pS}$ (Weiss and Horn, 1986; Cannon et al., 1991) and is effectively blocked by low concentrations $\left(K_{d}=10 \mathrm{~nm}\right)$ of TTX. Another type of $\mathrm{NaCh}$ is found in immature and denervated muscle (Diamond and Miledi, 1962; Redfern and Thesleff, 1971), has a conductance of about $10 \mathrm{pS}$ (Weiss and Horn, 1986), and is relatively resistant to thc blocking action of TTX $\left(K_{d}=1 \mu \mathrm{M}\right)$. These subtypes are encoded by different genes (Rogart et al., 1989; Trimmer et al., 1989; Kallen et al., 1990). We have used an RNase protection assay to show that the developmental switch in expression from the embryonic to the adult $\mathrm{NaCh}$ transcripts occurs over the same time period as the onset of $\mathrm{NaCh}$ aggregation measured electrophysiologically. This suggested that the two events might be related and that only the TTX-sensitive, mature $\mathrm{NaCh}$ could become concentrated at the synapse during development. However, loose-patch clamp recordings revealed that the distributions of both types of $\mathrm{NaCh}$ appeared to be regulated similarly and that both $\mathrm{NaCh}$ isoforms became concentrated at the neuromuscular junction.

Some of these results were presented previously in abstract form (Lupa et al., 1991).

\section{Materials and Methods}

All chemicals and reagents used in this study were purchased from Sigma Chemical (St. Louis, MO) unless otherwise indicated.

Muscle preparations. Muscle fibers were dissociated from rat flexor digitorum brevis (FDB) muscles as previously described (Bekoff and Betz, 1977; Lupa and Caldwell, 1991). Muscles were incubated in 2.5 $\mathrm{mg} / \mathrm{ml}$ collagenase (type B; Boerhinger-Mannheim, Indianapolis, IN), $1 \mathrm{mg} / \mathrm{ml} \mathrm{BSA}$, in Dulbecco's modified Eagle's medium (GIBCO), on a rotating wheel at $37^{\circ} \mathrm{C}$. Adult muscles were incubated for $2 \mathrm{hr}$, while muscles from younger animals required between 0.5 and $1.5 \mathrm{hr}$. Muscles were dissociated by gentle trituration using Pasteur pipettes of decreasing tip diameter. FDB cells were dissociated into a glass-bottom chamber for loose-patch recording, or onto $22 \times 22 \mathrm{~mm}$ glass coverslips for immunostaining.

The levator auris longus (LAL) muscle is a thin superficial muscle used to wiggle the ear (Angaut-Petit et al., 1987). The muscle was dissected from mice along with a portion of the outer ear, and pinned ventral side up in a glass-bottom chamber.

For both muscles the day of birth was considered postnatal day 0 (PN 0).

Loose-patch voltage-clamp recording. Loose-patch voltage-clamp recordings were made as previously described (Caldwell et al., 1986; Lupa and Caldwell, 1991). A fire-polished microelectrode (tip diameter, 5$15 \mu \mathrm{m}$ ) was slowly advanced against the muscle fiber until a seal resistance at least twice the electrode resistance $(100-400 \mathrm{k} \Omega$ ) was obtained. Suction was usually applied to improve the seal, though caution was used to avoid bleb formation, especially in enzyme-treated muscles (Milton and Caldwell, 1990). A steady hyperpolarizing potential was applied $(-50 \mathrm{mV}$ for FDB, $-70 \mathrm{mV}$ for LAL) that made the resting membrane potential of the patch more negative than that of the cell. This "holding potential" was applied for several minutes before recording in order to remove slow inactivation of NaChs (Almers et al., 1983). Depolarizing pulses $(4 \mathrm{msec}$ ) of different step sizes were then applied until the maximum inward current was measured.

Na current density was calculated assuming that the area of membrane voltage clamped was equal to the area under the pipette tip. In extrajunctional nembrane, loose-patch clamp estimates agree with those from radiolabeled TTX (Rogart, 1981), both estimates giving several hundred channels per square micrometer. At the end plate, however, the membrane is heterogeneous and several factors, some of them offsetting, complicate estimates of channel density. First, postsynaptic folds increase the membrane area enclosed by the pipette; this increase is about a factor of 2 (Ruff, 1992). If channels were uniformly distributed, this twofold increase in membrane area would double the apparent
$\mathrm{NaCh}$ density. Second, electron microscopic studies using immunocytochemistry (Flucher and Daniels, 1989) and radiolabeled scorpion toxin (Boudier et al., 1992) indicate that $\mathrm{NaChs}$ are concentrated in the depths of the postsynaptic folds and are absent or at low density on the crests of the folds where AChRs are concentrated. Thus, NaChs are segregated within postsynaptic membrane. Third, the loose-patch pipette records simultaneously from perijunctional membrane between synaptic terminal boutons, as well as from the troughs and crests of the postsynaptic folds. Therefore, the loose-patch current densities are an average over these different regions within the endplate.

Separation of the mature and immature populations of NaChs was achieved by pharmacological blockade of the mature, TTX-sensitive (TTX-S) NaChs. Fibers were recorded from and relocated by use of photographs and stage micrometer settings. The normal Ringer solution was removed with suction and replaced by Ringer with 300 nM TTX. This was usually repeated twice to make sure that the concentration of TTX was not diluted. The patch electrode was also removed and filled with the same TTX solution before recording. Assuming a $K_{d}$ of $10 \mathrm{~nm}$ for TTX-S NaChs (Gonoi et al., 1985; Weiss and Horn, 1986) and 1 $\mu \mathrm{M}$ for TTX-resistant (TTX-R) channels (Pappone, 1980), we calculate that 300 nM TTX will block $96.8 \%$ of the TTX-S NaChs as well as $23 \%$ of the TTX-R NaChs. We corrected values for TTX-R current obtained in $300 \mathrm{nM}$ TTX with the equation $\mathrm{NaI}_{\mathrm{TTX}}=\left(\mathrm{NaI}_{\mathrm{TOX}}-0.03\left(\mathrm{NaI}_{\mathrm{TOT}}\right)\right) /$ 0.74 , where $\mathrm{NaI}_{\text {TTX }}$ is the true TTX-R Na current, NaI $\mathrm{I}_{\text {Tox }}$ is the uncorrected current measured in the presence of $300 \mathrm{nM}$ TTX, and NaI is the current recorded in normal Ringer. Calculation of TTX-S and TTX-R currents using $K_{d}$ values in the range of 5-20 $\mu \mathrm{M}$ (TTX-S) and 1-3 $\mu \mathrm{M}$ (TTX-R) had minor effects on the absolute value of the current, but did not affect our conclusions.

Immunocytochemistry and video imaging. Rhodamine-conjugated $\alpha$-bungarotoxin (rho-Butx) was prepared by the method of Ravdin and Axelrod (1977). The LD3 monoclonal antibody (mAb), which recognizes an intracellular epitope of the TTX-S muscle $\mathrm{NaCh}$, was generously supplied by Drs. R. Barchi and S. Cohen of the University of Pennsylvania. This $\mathrm{mAb}$ has been shown to recognize a $200 \mathrm{kDa}$ band in immunoblots of rat skeletal muscle (Casadei and Barchi, 1987), and to stain surface membrane in cross sections of rat muscle (Haimovich et al., 1987).

To visualize $\mathrm{AChRs}$ on muscle fibers, preparations were incubated with $50 \mathrm{nM}$ rho-Butx for $0.5-2.0 \mathrm{hr}$ in a $36^{\circ} \mathrm{C}$ incubator, and then rinsed with PBS or Ringer solution. Immunofluorescent labeling was achicved on preparations that had been fixed in ice-cold $2.5 \%$ paraformaldehyde, $0.1 \%$ saponin in PBS for $25 \mathrm{~min}$ at $4^{\circ} \mathrm{C}$. The cells were rinsed in PBS, incubated in $0.1 \mathrm{M}$ glycine for $25 \mathrm{~min}$ at room temperature to reduce background fluorescence, and permeabilized with $0.1 \%$ Triton $\mathrm{X}-100$ or saponin for $10 \mathrm{~min}$. Nonspecific antibody binding was reduced by pretreatment with $5 \%$ BSA, 3\% fetal bovine serum in PBS (blocking solution) for $15-30 \mathrm{~min}$. The cells were then incubated overnight at $4^{\circ} \mathrm{C}$ with a 1:50 dilution of the LD3 monoclonal antibody in blocking solution. After several rinses with PBS, cells were labeled for $1 \mathrm{hr}$ with FITC-coupled goat anti-mouse secondary antibody. Coverslips were mounted on slides with a glycerol-based solution containing $p$-phenylenediamine (Platt and Michael, 1983). As a control for nonspecific antibody binding the primary antibody was omitted. Only a faint, uniform background staining and occasional weak labeling of cell nuclei were observed in this case.

Slides were viewed either on a Zeiss Axiophot microscope and photographed using TMAX 400 film, or on a Nikon Diaphot inverted microscope and photographed through an SIT camera coupled to a Silicon Graphics (Mountain View, CA) Iris computer, as previously described (Lupa and Caldwell, 1991).

RNase protection assay. To obtain TTX-S NaCh (SkM1) and TTX-R $\mathrm{NaCh}$ (SkM2) cDNAs, total RNA was isolated from extensor digitorum longus muscle that had been denervated 10-14 d. The RNA was reverse transcribed with oligo-dT primers and the cDNAs amplified by PCR. The amplified DNA was about 850 base pairs (bp). The 5' PCR primer was nucleotides 3835-3866 of rat brain I (see Noda et al., 1986) and had additional nucleotides added at the $5^{\prime}$ end to create recognition sites for restriction enzymes SphI and IHind III. The 3' PCR primer was nucleotides $4660-4681$ of rat brain I with recognition sites for Sall and EcoRI. The PCR products were cloned into MI 3 phage, and individual clones were plaque-purified and sequenced. An SkM1 clone was digested with enzymes AccI and SphI and subcloned into pGEM4; this cDNA was nucleotides 3253-3626 of Trimmer et al. (1989). An SkM2 clone was digested with PstI and SalI and subcloned into pGEM4; this cDNA was nucleotides 4439-4844 of Rogart et al. (1989). Antisense riboprobes 

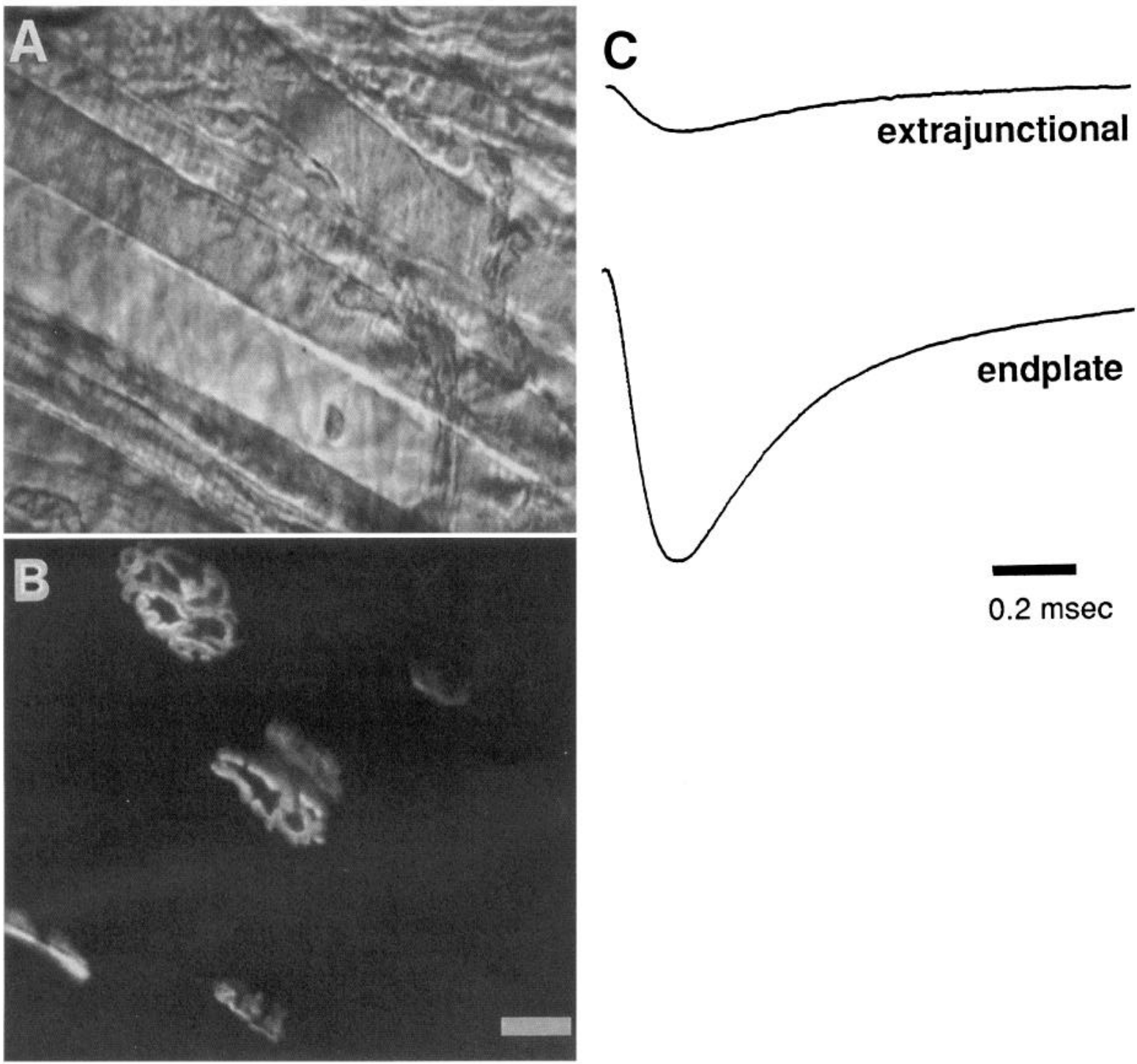

$0.2 \mathrm{msec}$

Figure 1. A, Hoffman modulation-contrast image of an adult mouse LAL muscle. The myelinated nerve can be seen to course over several fibers and terminate in neuromuscular junctions. $B$, The same field as $A$, seen under epifluorescent illumination to reveal the postsynaptic membrane labeled with rho-Butx. Scale bar, $15 \mu \mathrm{m}$. $C$, Examples of $\mathrm{Na}$ current recordings made with a loose-patch clamp electrode (10 $\mu \mathrm{m}$ tip diameter) from the extrajunctional membrane (top trace) and end plate membrane (bottom trace) of an identified LAL fiber. On this fiber the extrajunctional Na current density was $23.3 \mathrm{~mA} / \mathrm{cm}^{2}$, and the current density at the end plate was $110 \mathrm{~mA} / \mathrm{cm}^{2}$.

were produced using SP6 polymerase on linearized template (Melton et al., 1984) in the presence of ${ }^{32} \mathrm{P}-\mathrm{CTP}$ (Amersham). Probes were used after ethanol/ammonium acetate precipitation; the TTX-R probe was gel purified for use in some assays.

Total cellular RNA was isolated from rat tissue as described by Chomczynski and Sacchi (1987). RNA was stored at $-80^{\circ} \mathrm{C}$ as a precipitate in guanidinium plus isopropanol. cRNA probe $\left(1-2 \times 10^{6} \mathrm{cpm}\right)$ was hybridized to $30-40 \mu \mathrm{g}$ total RNA in $50 \mu \mathrm{l}$ of hybridization buffer [40 mM PIPES (pH 6.4), 1 mm EDTA, $0.4 \mathrm{~m} \mathrm{NaCl}, 80 \%$ formamide] overnight at $45^{\circ} \mathrm{C}$. Unhybridized RNA was digested with ribonucleases $\mathrm{A}$ $(40 \mu \mathrm{g} / \mathrm{ml})$ and $\mathrm{T} 1(2 \mu \mathrm{g} / \mathrm{ml})$ for $1 \mathrm{hr}$ at $30^{\circ} \mathrm{C}$. The RNases were destroyed by addition of $35 \mu \mathrm{g}$ of proteinase $\mathrm{K}$, and the samples were phenolchloroform extracted once. The remaining RNA was EtOH precipitated for $1 \mathrm{hr}$ at $-20^{\circ}$, washed once with $75 \% \mathrm{EtOH}$, and dried. The protected probes were analyzed on a $5 \%$ polyacrylamide, $7 \mathrm{M}$ urea gel and exposed to Amersham Hyperfilm with an intensifying screen at $-80^{\circ} \mathrm{C}$. To control for nonspecific hybridization, the assay was run on samples of rat liver RNA and yeast tRNA; no bands were observed in these lanes.

To quantify the assay, probes were hybridized to known amounts of the sense strand of each NaCh probe RNA. Digitized images of the autoradiographs were then obtained using an image analysis system comprised of an Apple Macintosh IIx computer equipped with a Data
Translation video capture card, a COHU video camera (model 48152000), and the NIH IMAGE 1.43 analysis software (a public domain program published by the National Technical Information Service). For image acquisition, the automatic gain and black adjust controls in the camera were turned off to prevent the camera from adjusting for variations in light intensity within and between autoradiographs. A calibration curve was generated by taking pixel intensity measurements for bands obtained with known amounts of the sense strand for each probe. This curve was then automatically applied to all measurements taken from the experimental lanes.

The probe for the TTX-R channel protected a single band that corresponded to the full-length probe minus the 25 nucleotide (nt) polylinker tail (405 nt). The TTX-S riboprobe, however, protected one band corresponding to the full-length probe without polylinker (374 nt) and another band representing a protected piece about $15 \mathrm{nt}$ shorter (see Fig. 4; see also Donahue et al., 1991). This doublet may be due to degeneracy in the original primers used for PCR amplification; the primers were identical to a $20 \mathrm{bp}$ stretch of the rat brain $\mathrm{NaCh}$ III and did not match the TTX-S NaCh cDNA at two sites. These 1 and 2 bp mismatches may only be recognized by the RNases $\sim 50 \%$ of the time, causing the doublet. It is also possible that the two bands are evidence for alternative splicing in this region of the TTX-S NaCh. 


\section{Results}

The thin LAL muscle proved to be a useful preparation for loose-patch clamp recording from identified single muscle fibers. Much of this muscle is one to two layers thick, and it was often possible to find single fibers lying completely isolated in the intact muscle. When $\mathrm{Na}$ currents were recorded from such fibers (Fig. 1), it was found that the $\mathrm{Na}$ current density at adult end plates was $84.1 \pm 7.0 \mathrm{~mA} / \mathrm{cm}^{2}$, which was slightly lower than the reported current densities at rat FDB, mouse FDB, or rat omohyoid neuromuscular end plates (Caldwell et al., 1986; Lupa and Caldwell, 1991; Ruff, 1992). The extrajunctional current density in mouse LAL muscles was $19.3 \pm 1.7 \mathrm{~mA} / \mathrm{cm}^{2}$, which was two to three times higher than in the rat or mouse FDB or rat omohyoid. The $\mathrm{NaCh}$ density at mouse LAL end plates was thus four- to fivefold higher than in extrajunctional membrane.

\section{Development of $\mathrm{NaCh}$ density at the end plate}

In order to study the development of this synaptic specialization, loose-patch clamp recordings were made on muscles taken from postnatal mice and rats of different ages. End plates were visualized with rho-Butx, and Na currents were recorded with the pipette directly over the end plate. Na current density at the end plate was then compared to the density found in an extrajunctional region approximately $200 \mu \mathrm{m}$ away, where the $\mathrm{Na}$ current density is relatively uniform and low (Caldwell et al., 1986; Lupa and Caldwell, 1991).

During the first postnatal week the $\mathrm{Na}$ current density at the end plate was low $\left(5-10 \mathrm{~mA} / \mathrm{cm}^{2}\right)$ and not significantly different from that found in extrajunctional regions (Fig. $2 A$ ). The end plate $\mathrm{NaCh}$ density began to increase during the second postnatal week, when the current density at the end plate became nearly twice the density in the extrajunctional membrane. From birth to PN 20 the Na current density at the end plate increased 7.3-fold, while the extrajunctional density doubled. Between 3 weeks and 3 months after birth the end plate Na current density increased a further $40 \%$, and the extrajunctional current density increased about $20 \%$ (Fig. $2 A$ ). The aggregation of $\mathrm{NaChs}$ at the neuromuscular junction is thus not an early event in synapse formation, in contrast to the AChR and several other synaptic molecules (Bloch, 1989; Froehner, 1991). Development of a high $\mathrm{NaCh}$ density at the end plate appears to be a slow process and a part of the synaptic maturation that occurs after birth. The aggregation of $\mathrm{NaChs}$ at the end plate coincides with another postsynaptic maturational event: the elaboration of subsynaptic membrane folds (Matthews-Bellinger and Salpeter, 1983). It is possible that the same process could regulate both and that molecules associated with the postsynaptic troughs cause $\mathrm{NaCh}$ to become concentrated there (see Discussion).

Enzymatically dissociated rat FDB muscle fibers were uscd to map the distribution of $\mathrm{NaChs}$ near the end plate (Fig. $2 B$ ). For these experiments the earliest age examined was PN 13. When the $\mathrm{Na}$ current density was mapped along postnatal rat FDB muscle fibers, an elevated $\mathrm{NaCh}$ density occurred exclusively in the end plate region, with no evidence of an increased density in perijunctional regions until PN 35. The slow time course of aggregation was also evident since even after 35 postnatal days the $\mathrm{Na}$ current density at FDB end plates was still less than half the density recorded from adult ( $>100 \mathrm{~d}$ old) fibers.

The gradual accumulation of $\mathrm{NaCh}$ was visualized with an $\mathrm{mAb}$ specific for the TTX-S muscle Na channel (Fig. 3). No difference in $\mathrm{NaCh}$ labeling was noted between end plate and extrajunctional regions until PN 17 . This probably reflected the lower sensitivity of immunocytochemistry compared to loosepatch clamp recording, as well as the fact that the antibodies recognize only the adult form of the $\mathrm{NaCh}$. At some of the early $\mathrm{NaCh}$ clusters only parts of end plates appeared labeled more intensely than the rest of the fiber (Fig. 3, PN 17). These results imply that the process of $\mathrm{NaCh}$ aggregation occurs at different rates in different parts of the postsynaptic structure but do not distinguish between localized insertion or immobilization of $\mathrm{NaChs}$ at the end plate.

From the earliest times that a synaptic $\mathrm{NaCh}$ concentration could be observed, the region of high immunofluorescence was confined to the patch of membrane that was also labeled with rho-Butx. At this time only postjunctional membrane opposite the nerve terminal binds detectable amounts of rho-Butx (Bevan and Steinbach, 1977; Smith and Slater, 1983), and the NaChs thus aggregated in postsynaptic membrane opposite the nerve terminal. This is not true for most of the AChR clusters that first form on embryonic muscle. The initial patches of AChR appear in the vicinity of the growth cone and neurite, usually overlapping but not confined to the membrane in contact with the nerve ending (see also Smith and Slater, 1983; Lupa and Hall, 1989; Dahm and Landmesser, 1991).

\section{Expression of different NaCh subtypes during development}

Two types of $\mathrm{NaCh}$ have been described in mammalian skeletal muscle based on a difference in affinity for the neurotoxin TTX (Redfern and Thesleff, 1971; Rogart, 1981). It has been shown that these two proteins are encoded by different genes and that the switch in expression from the TTX-R NaCh to the mature, TTX-S form occurs between birth and the third postnatal week (Sherman and Catterall, 1982; Gonoi et al., 1989; Kallen et al., 1990; Trimmer et al., 1990). Since aggregation of $\mathrm{NaChs}$ at the end plate was first observed at about the same time, it was possible that only the mature form was capable of aggregation during development. The synthesis of the mature subtype could be controlled at either transcription or translation of the protein. Therefore, we determined the levels of both RNA and protein for each subtype in the same muscle. An RNase protection assay was used to measure the changes in mRNA for these two proteins during development of the LAL muscle, and loose-patch clamp recordings were used to measure the level of functional protein.

${ }^{32} \mathrm{P}$-labeled RNA probes for portions of the third cytoplasmic loops of the TTX-S (SkM1; Trimmer et al., 1990) and TTX-R (SkM2; Rogart et al., 1989; Kallen et al., 1990) NaChs (i.e., between domains III and IV) were hybridized to total cellular RNA extracted from rat LAL muscles of various ages. As shown in Figure $4 A$, both types of $\mathrm{NaCh}$ RNA were present at PN 5. The embryonic, TTX-R NaCh mRNA decreased in abundance on PN 10, and was barely detectable by PN 15. In contrast, the TTX-S NaCh mRNA increased in abundance through PN 20, and increased further between PN 20 and adult (AD; $>4$ months). The relative abundance of mRNA for each $\mathrm{NaCh}$ isoform was quantified and normalized to the maximum signal obtained (TTX-S NaCh expression in adult muscle RNA). The highest expression of TTX-R NaCh mRNA was found in embryonic day 19 muscle, which was the earliest time examined; the level of TTX-R NaCh transcripts was about 10 times higher than TTX-S NaCh transcripts at this time, but the level of TTX-R $\mathrm{NaCh}$ transcripts was only about $35 \%$ of the maximum level of 
A

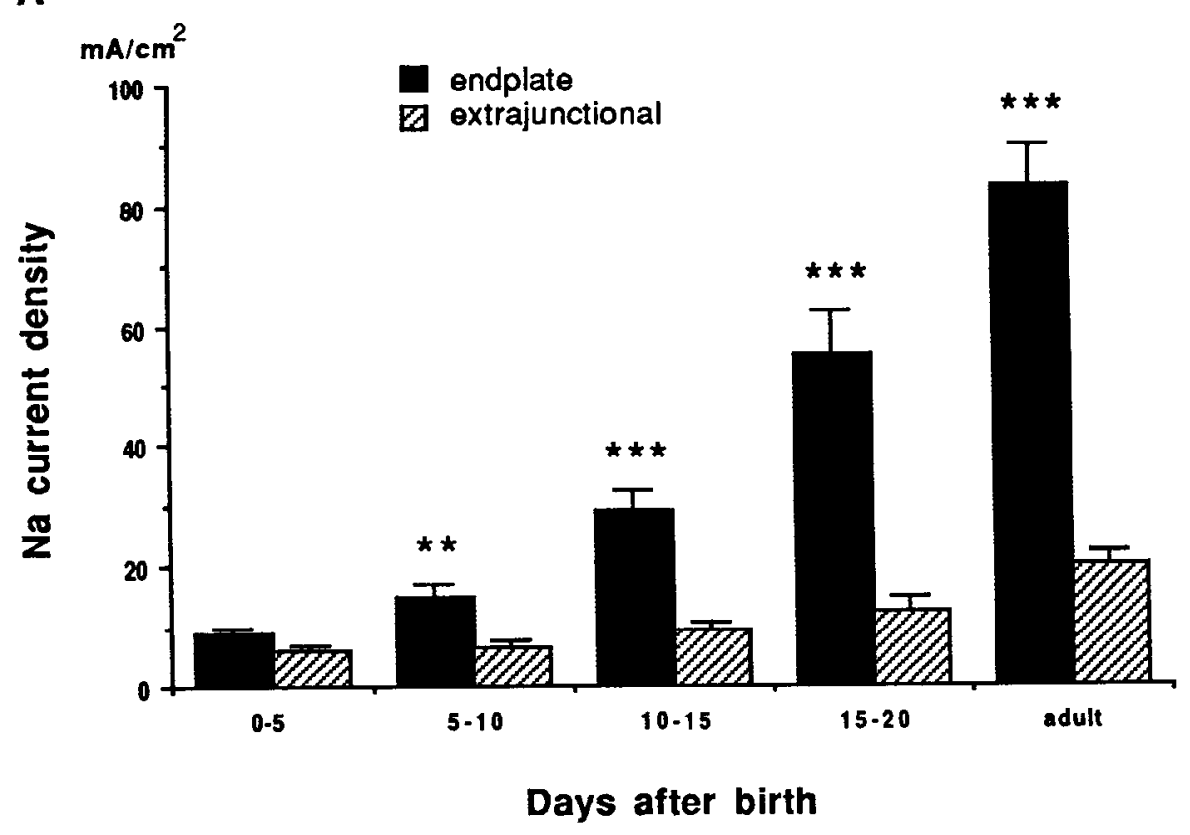

B

Figure 2. A, Mean Na current density at the end plate region (solid bars) and extrajunctional region (hatched bars) of mouse LAL muscles of various ages; adults were $>100 \mathrm{~d}$ old. Bars represent the mean \pm SEM of 22 fibers. ${ }^{* *}, p \leq$ $0.01 ; * * *, p \leq 0.001$. B. Maps of $\mathrm{Na}$ current density on dissociated rat FDB muscle fibers from animals of different ages. Recordings at $0 \mu \mathrm{m}$ were made directly over the end plate, visualized by rho-Butx. Each point represents the mean \pm SEM of recordings from 5-10 muscle fibers.

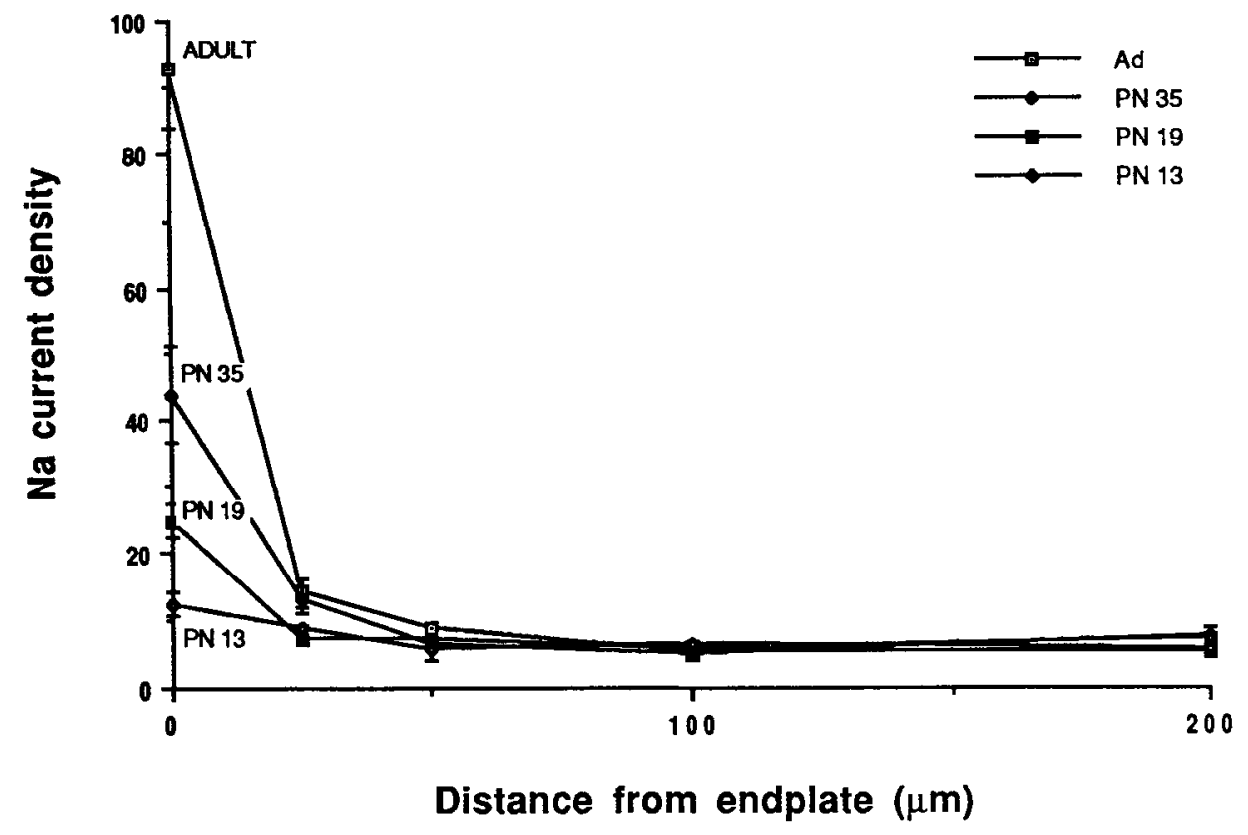

TTX-S NaCh mRNA found in adult muscle (Fig. 4B). Expression of TTX-R NaCh mRNA fell sharply by about $70 \%$ by PN 15 , and became gradually reduced to a negligible $(<1 \%)$ amount in the adult. The abundance of TTX-S NaCh mRNA increased most sharply between PN 5 and PN 20, but increased further between PN 20 and adult. These results showed that the initiation of the shift in expression from the TTX-R to TTX-S isoform preceded the onset of $\mathrm{NaCh}$ aggregation at the end plate.

To test the hypothesis that only the TTX-S NaCh could become concentrated at the end plate during development, loosepatch recordings were made at end plates and extrajunctional areas ( $\sim 200 \mu \mathrm{m}$ away from the end plate), both in the presence and absence of $300 \mathrm{nM}$ TTX. This concentration of TTX blocks $97 \%$ of the TTX-S channels, as well as $23 \%$ of the TTX-R NaChs. We calculated the true TTX-R current for each set of recordings (see Materials and Methods), and then substracted this corrected value from the total $\mathrm{Na}$ current measured in normal Ringer solution to obtain the actual TTX-S Na current. In this way we could monitor changes in each population of $\mathrm{NaCh}$. Figure 5 shows the corrected values of TTX-S and TTX-R Na current density measured in end plate and extrajunctional membrane. The TTX-S Na current density at the end plate during 


\section{rho-Butx}

PN 10

PN 17

PN 25

Adult
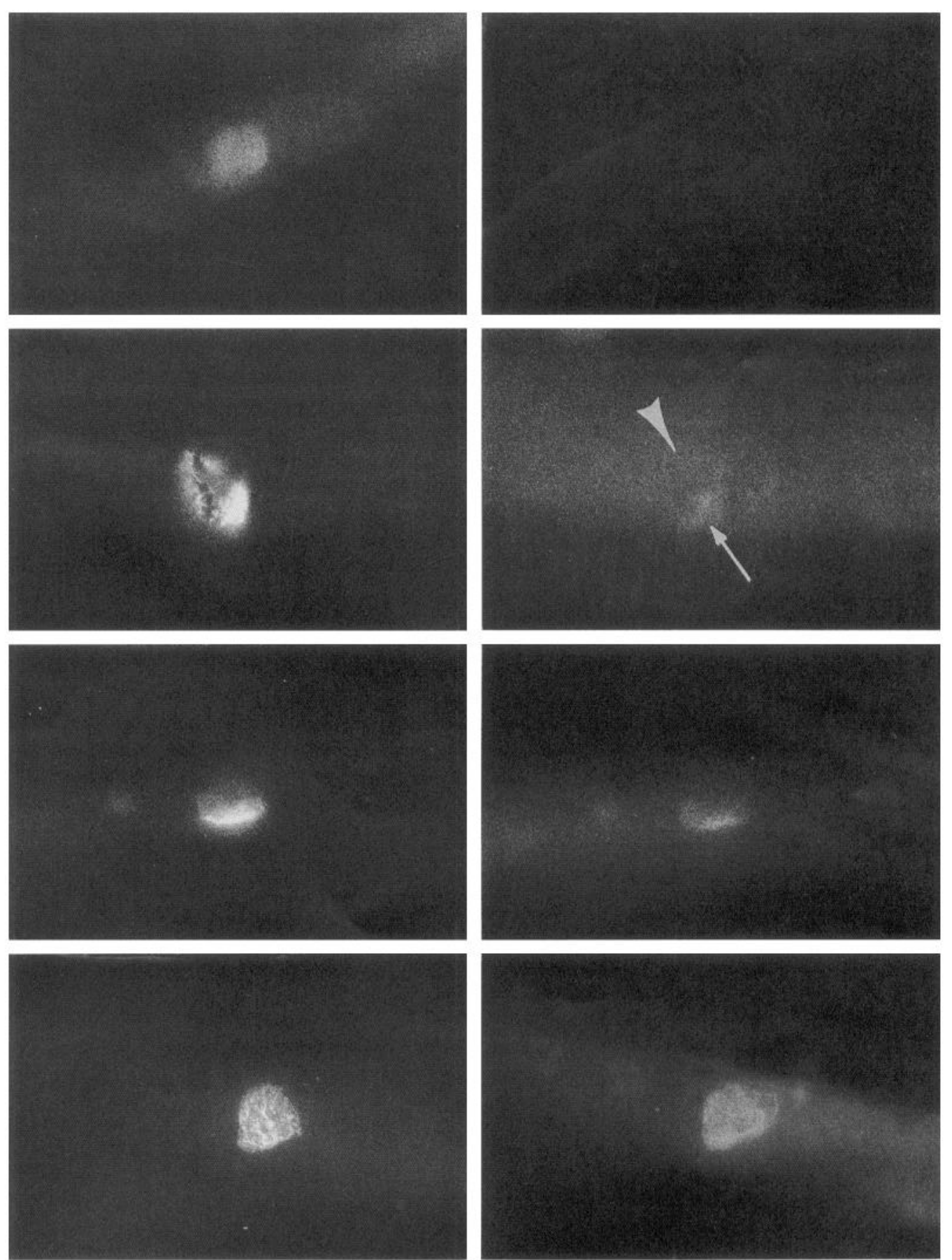

Figure 3. Distribution of $\mathrm{AChRs}$ and $\mathrm{NaChs}$ at developing neuromuscular junctions. Dissociated FDB muscle fibers from rats of various ages were labeled with rho-Butx and with antibodies specific for the TTX-S muscle NaCh. For each time point, the same field was photographed with rhodamine and fluorescein filters. An increased immunofluorescence was first noted at the end plate on $P N 17$, and at this time one part of the end plate (arrow) was labeled more intensely than the rest of the synaptic membrane (arrowhead). Scale bar: $50 \mu \mathrm{m}$ for $P N 10, P N 17$, and $P N$ 25; $40 \mu \mathrm{m}$ for Adult (6 mo old). 


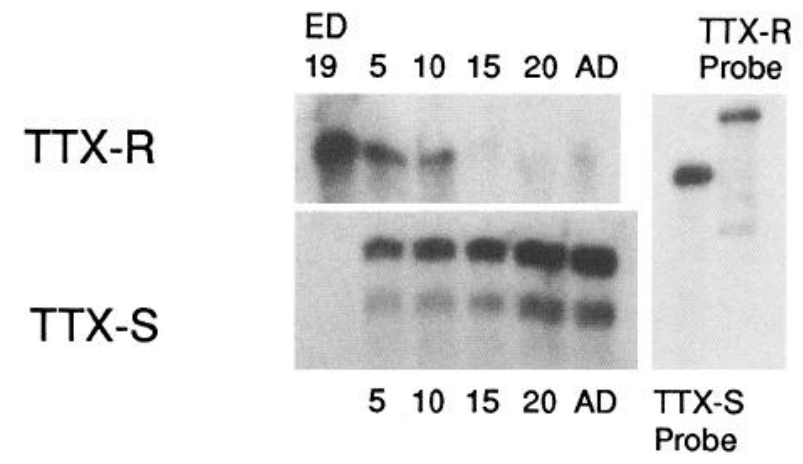

Figure 4. Detection of muscle $\mathrm{NaCh}$ isoforms during development. RNase protection analysis of LAL muscle total RNA samples $(35 \mu \mathrm{g})$ isolated from rats of various ages. A: Top band, Hybridization of ${ }^{32} \mathrm{P}$-labeled probe for the TTX-R NaCh to total RNA extracted from embryonic day 19 and PN 5, 10, 15,20 , and $120(A D)$ muscle. Bottom bands, The same RNA samples probed with antisense ${ }^{32} \mathrm{P}$-labeled RNA probe for the TTX-S NaCh (embryonic day 19 RNA was not tested in this experiment). The far right two lanes show the probes for the TTX-R (upper right) and TTX-S (lower left) NaChs. Autoradiographs were exposed $13 \mathrm{hr}$ for the TTX-S NaCh, $17 \mathrm{hr}$ for the TTX-R $\mathrm{NaCh} . B$, The percentage change for the TTX-S (open squares) and TTX-R (solid diamonds) $\mathrm{NaCh}$ messages in developing muscle. Quantitation was achieved by calibrating a digital densitometric imaging program with bands obtained from RNase protection analysis of known quantities of the sense strand for each probe (see Materials and Methods). Each point represents mean of two to six measurements. Data was normalized to the maximum signal obtained for the TTX-S probe in adult muscle.

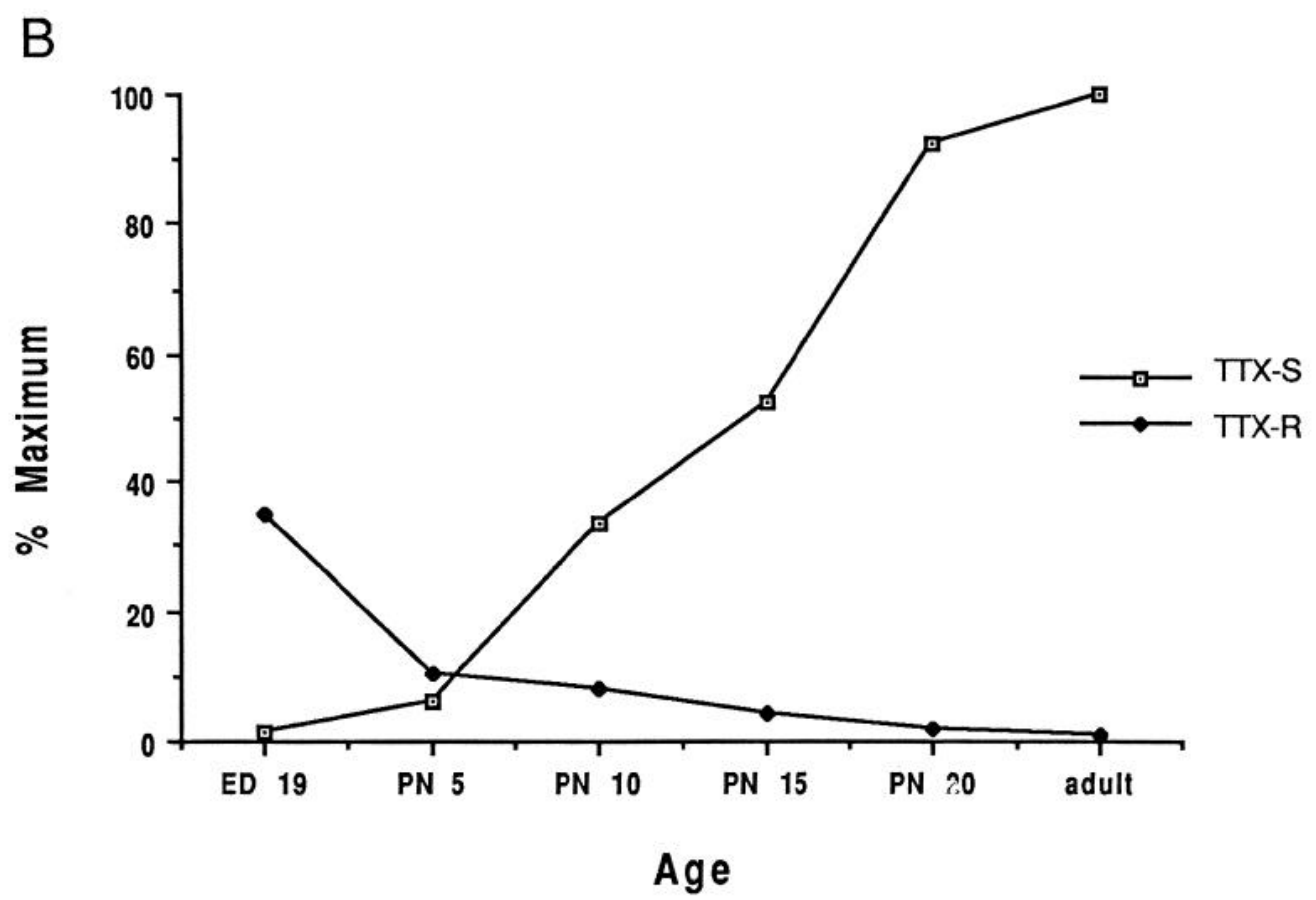

the first five postnatal days was extremely low $(1.6 \pm 0.25 \mathrm{~mA}$ / $\mathrm{cm}^{2}$ ), but was significantly $(p<0.05)$ greater than the TTX-S current in extrajunctional membrane at this time $(0.9 \pm 0.09$ $\mathrm{mA} / \mathrm{cm}^{2}$ ). While the extrajunctional TTX-S Na current increased during development to $17.8 \pm 2.11 \mathrm{~mA} / \mathrm{cm}^{2}$ in adult muscle, the growth in TTX-S current density was much greater at the end plate, thus producing a four- to fivefold concentration of these channels. The TTX-S Na current density at adult end plates was $76.0 \pm 7.39 \mathrm{~mA} / \mathrm{cm}^{2}$.

During PN 1-5 the TTX-R NaCh was the predominant subtype $(86 \%)$ in both synaptic and extrajunctional membrane. At this time the TTX-R current density at the end plate $(7.0 \pm$ $0.88 \mathrm{~mA} / \mathrm{cm}^{2}$ ) was not significantly different than the current density in the extrajunctional membrane $\left(4.7 \pm 0.38 \mathrm{~mA} / \mathrm{cm}^{2}\right.$; $p>0.05)$. During postnatal life the TTX-R Na current density at the synapse remained nearly constant, and in the adult the TTX-R current density was $8.1 \pm 1.27 \mathrm{~mA} / \mathrm{cm}^{2}$. However, TTX-R NaChs also appeared to become concentrated at the end plate because extrajunctional TTX-R Na current density decreased to $1.4 \pm 0.30 \mathrm{~mA} / \mathrm{cm}^{2}$ in the adult. Thus, although the expression of the TTX-R and TTX-S forms of the $\mathrm{NaCh}$ was regulated in an anticoordinate way during development, the highest density of both was found at the end plate after the first postnatal week.

\section{Discussion}

We have demonstrated that the concentration of $\mathrm{NaCh}$ at the neuromuscular junction first appears during the second postnatal week and is not complete until several months after birth. Loose-patch clamp recording and immunofluorescent labeling revealed that the initiation of $\mathrm{NaCh}$ aggregation is confined to the end plate area from the earliest stages of aggregation. These results stand in contrast to the first clusters of AChR and several basal lamina and cytoskeletal proteins, which begin to appear hours after neurite-myotube contact (Anderson and Cohen, 1977) and at first are not confined to the membrane directly apposing the neurite ending (Smith and Slater, 1983; Lupa and Hall, 1989; Dahm and Landmesser, 1991). Along with previous work show- 


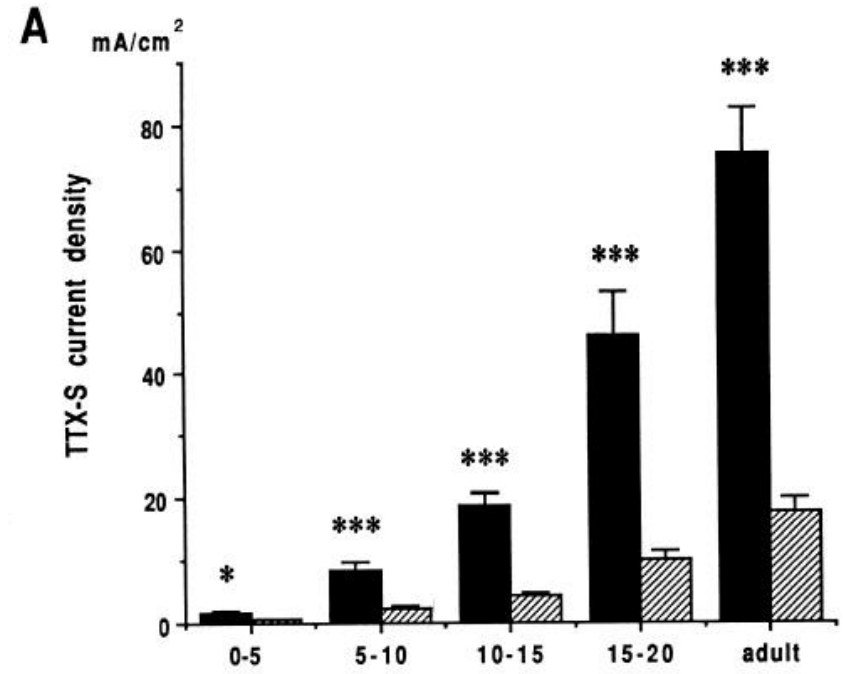

B

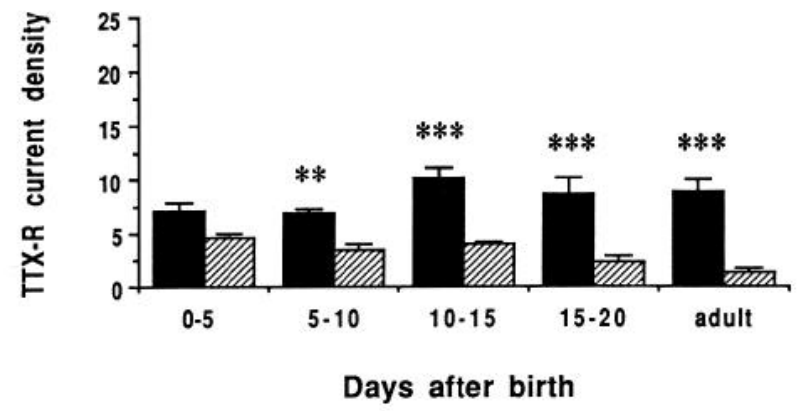

Figure 5. Pharmacological separation of TTX-S and TTX-R Na currents. Bars represent the $\mathrm{Na}$ current density at the end plate (solid bars) and in extrajunctional membrane (hatched bars). Data are mean \pm SEM of 15-20 fibers for each time point. $A$, Current density attributable to the TTX-S, adult NaChs. $B$, Current density attributable to the TTX$\mathrm{R}$, embryonic NaChs. ${ }^{*}, p<0.05 ;{ }^{* *}, p<0.01 ;{ }^{* * *}, p<0.001$.

ing that the basal lamina protein agrin has little influence over the distribution of $\mathrm{NaChs}$ (Lupa and Caldwell, 1991), the present results indicate that different mechanisms control the distributions of AChRs and $\mathrm{NaChs}$.

The process of $\mathrm{NaCh}$ aggregation differs in at least three ways from that of most synaptic molecules that have been studied. First, the initial clusters of several synaptic proteins at the neuromuscular junction are composed of the immature forms of these proteins [e.g., AChR (Gu and Hall, 1988) and AChE (Massoulie and Bon, 1982)]. Second, these early patches are usually loosely colocalized with the differentiating nerve ending, and coalesce over several days to weeks into the postsynaptic membrane opposite the nerve terminal. Finally, postnatally the immature forms of the proteins are replaced with the mature forms. In contrast to this, the initial clusters of $\mathrm{NaChs}$ are made up of both forms of the protein, aggregation occurs within the boundaries of the end plate, and the switch in $\mathrm{NaCh}$ expression occurs concomittantly with this process.

Angelides (1986) reported that $\mathrm{NaChs}$ labeled with fluorescently conjugated toxins formed clusters at sites of neurite-induced AChR clusters on chick myotubes in vitro. The results reported here show that aggregation of $\mathrm{NaChs}$ is one of the latest
Birth

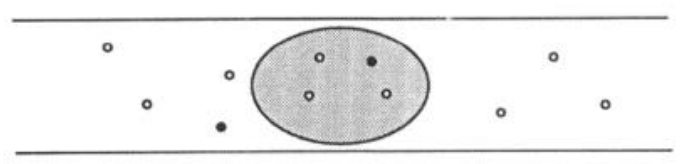

PN 15

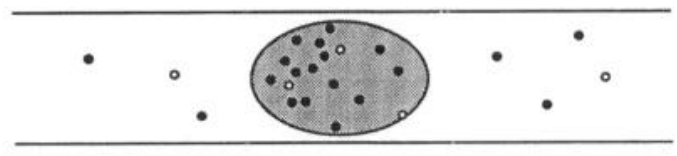

PN 30

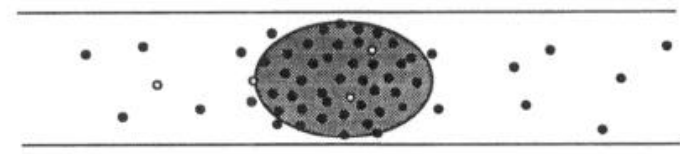

Figure 6. Diagram depicting changes in $\mathrm{NaCh}$ distribution during maturation of the neuromuscular junction (shaded oval) from birth to postnatal day 30 (PN 30). Open circles represent immature, TTX-R NaChs; solid circles represent mature, TTX-S NaChs. This figure illustrates several processes that are occurring on muscle fibers postnatally: (1) downregulation of expression of the TTX- $\mathrm{R} \mathrm{NaCh}$, and upregulation of expression of the TTX-S NaCh, (2) aggregation of both types of $\mathrm{NaCh}$ isoforms at the end plate, and (3) asynchronous, nonuniform development of this aggregate within the boundaries of the end plate.

aspects of maturation at this synapse, and suggest that it would only be found at a stage of development seldom achieved in culture. Several differences between these two studies might provide a possible explanation for this apparent contradiction. First, development in vitro may not always faithfully reproduce what happens in vivo. Second, the chick cultures were 2-3 weeks old (K. Angelides, personal communication) and thus might have survived long enough to produce more mature synaptic contacts. Finally, this might reflect a species difference between rodents and chicks.

The $\mathrm{NaCh}$ densities measured at the end plate and extrajunctional regions of LAL muscles differed quantitatively from those reported previously in other muscles. The reduced synaptic density may be related to the fact that the LAL muscle is made up of mixed metabolic fiber types (Angaut-Petit et al., 1987), and slow-twitch muscle fibers have been shown to possess a lower concentration of $\mathrm{NaCHs}$ in the end plate and perijunctional region (Milton et al., 1992; Ruff, 1992). The higher density of extrajunctional $\mathrm{NaChs}$ might be advantageous for action potential conduction in LAL muscle fibers, some of which are several centimeters long and 50-100 $\mu \mathrm{m}$ in diameter. Increasing the length of a fiber may require more rapid action potential propagation to ensure simultaneous contraction over the fiber length. An increase in fiber diameter creates an additional capacitive load from the transverse tubule membrane; charging this additional membrane would reduce the speed of propagation unless there is a compensatory increase in $\mathrm{Na}$ current density.

\section{Role of postsynaptic folding in NaCh aggregation}

Our results provide additional evidence for the correlation between the postjunctional folding and increased $\mathrm{NaCh}$ density at the end plate (Flucher and Daniels, 1989). The presence of a heightened $\mathrm{NaCh}$ density in this part of the subsynaptic mem- 
brane suggests that the folds may exist as a localized voltagedependent amplifier (see Vautrin and Mambrini, 1989), acting to raise the safety margin for transmission in order to counteract synaptic fatigue. The time of appearance of the postjunctional folds and $\mathrm{NaCh}$ aggregation coincides with a developing need for such a structure. As the muscle fiber grows larger and the postnatal myelination of motor axons proceeds, a high $\mathrm{NaCh}$ density adjacent to the AChR-rich membrane can help the muscle cell maintain its response to high-frequency nerve impulses.

The temporal correlation between the increase in $\mathrm{Na}$ current density and development of postjunctional folds raises the question of the relationship between these two events. We believe that the 5-10-fold higher current density found at end plates cannot be simply explained by a proportionately higher area of membrane under the patch pipette. (1) Ruff (1992) used capacitance measurements with loose-patch electrodes similar to ours in order to estimate the increase in membrane area due to folding in end plate patches. He found a twofold difference in capacitance between end plate and extrajunctional membrane; this would mean that postjunctional folding could account for at most a twofold increase in current density at the synapse, assuming that $\mathrm{NaChs}$ were distributed uniformly in the postjunctional membrane. (2) Flucher and Daniels (1989; see also Boudier et al., 1992) used immunocytochemistry to show that NaChs were not distributed uniformly in the postjunctional membrane, but were concentrated in the troughs and nearly absent from the crests of the folds, which has been estimated to comprise $\sim 30 \%$ of the postsynaptic surface area (Matthews-Bellinger and Salpeter, 1983). Thus, the effect of membrane folding on current density measurements in end plate patches is reduced to approximately 1.7 -fold. (3) Perijunctional membrane possesses a two to four times higher $\mathrm{Na}$ current density than extrajunctional membrane and there is no membrane folding. Therefore, the 5-10-fold higher Na current density at the end plate cannot be simply a consequence of additional postsynaptic membrane in end plate patches. We speculate that the junctional folds have specialized cytoskeletal or extracellular matrix proteins necessary for $\mathrm{NaCh}$ aggregation (Flucher and Daniels, 1989; Froehner, 1991).

\section{Regulation of NaCh isoforms during aggregation}

This is the first study to compare the developmental appearance of NaCh mRNAs and proteins in the same muscle, and it confirms earlier studies that focused on either $\mathrm{NaCh}$ mRNA (Kallen et al., 1990; Trimmer et al., 1990) or protein (Sherman and Catterall, 1982; Gonoi et al., 1989). A striking aspect of our results was the high level of TTX-S mRNA compared to TTX-S channels present at PN 5. At this time approximately equal amounts of TTX-R and TTX-S message were present, but only $10-20 \%$ of the Na current was sensitive to TTX. By comparing the temporal appearance of the RNA and current corresponding to these two $\mathrm{NaCh}$ isoforms, we estimated a 2-3 d lag between expression of the RNA and detection of functional channels in the membrane. This is consistent with studies of denervated muscle in which TTX-R Na current is not detected until $3 \mathrm{~d}$ after denervation (Redfern and Thesleff, 1971; Lupa and Caldwell, unpublished observations).

Pharmacological blockade of NaChs with TTX allowed us to compare the distributions of the mature and immature $\mathrm{NaCh}$ isoforms during development. By assuming a $K_{d}$ of $10 \mathrm{~nm}$ for TTX-S NaChs and $1 \mu \mathrm{M}$ for TTX-R NaChs, we calculated the $\mathrm{Na}$ current densities attributable to each of these two isoforms.
We found that the TTX-S current density increased over the entire muscle cell surface, but that the rate of increase was greatest at the end plate, producing a four- to fivefold concentration of TTX-S channels at adult end plates. TTX-R NaChs also became concentrated at the neuromuscular junction, but through a different pattern of changes. The TTX-R Na current density remained virtually unchanged at the end plate from birth to adulthood, but gradually became reduced in extrajunctional membrane. These changes could be explained by the overlapping occurrence of two separate processes: changes in $\mathrm{NaCh}$ subtype expression and membrane distribution (Fig. 6). The abundance of TTX-R NaCh mRNA and protein in LAL muscles decreased over the first 3 postnatal weeks, while the amount of TTX-S NaCh mRNA and protein gradually increased. At the same time, both types of $\mathrm{NaCh}$ were becoming aggregated in the postsynaptic membrane. This would explain the constancy of TTX-R NaCh density at the end plate since a decrease in TTX-R NaChs, due to the transcriptional switch in expression, was effectively counterbalanced by an increase in density due to aggregation. Expression of the two $\mathrm{NaCh}$ isoforms may also be regulated differently in synaptic and extrasynaptic nuclei: TTX-S NaCh mRNA expression may be increased in all the muscle nuclei while expression of TTX-R NaCh mRNA may be downregulated in extrasynaptic nuclei, as has been shown for the AChR (Fontaine et al., 1988; Goldman and Staple, 1989).

It was surprising to find any TTX-R Na current in normal adult muscle. In similar experiments no TTX-R Na current could be detected in FDB muscle fibers dissociated from adult innervated rat or mouse muscle (Caldwell and Milton, 1988; Lupa and Caldwell, unpublished observations). After correcting for unblocked TTX-S channels, we calculate that approximately $8.3 \mathrm{~mA} / \mathrm{cm}^{2}$ of the end plate current density must have arisen from TTX-R NaChs. There is evidence indicating a low expression of the immature form of some proteins in mature muscle fibers. Thesleff et al. (1974) have previously reported observing a small sodium-dependent electrogenic activity in TTX-treated innervated adult rat skeletal muscle, but only in the end plate region. Also, patch-clamp recording of adult mouse FDB muscle fibers revealed that about $3 \%$ of the AChR-activated channels in both extrajunctional and synaptic membrane had characteristics of the low-conductance, immature type of AChR channel (Brehm and Kullberg, 1987). It is possible that a low level of expression of the immature $\mathrm{NaCh}$ is maintained even in mature muscle, and an extremely low level of TTX-R RNA was detected in adult muscle RNA with the RNase protection assay (Fig. 4) and with Northern analysis (Kallen et al., 1990).

\section{Mechanisms of $\mathrm{NaCh}$ aggregation}

Several mechanisms could produce this high concentration of $\mathrm{NaChs}$ at the neuromuscular junction. First, it may be that the synaptic nuclei clustered under the postsynaptic membrane are specialized in some way, either to produce a high level of $\mathrm{NaChs}$ in this domain of the muscle or to express a novel $\mathrm{NaCh}$ isoform that aggregates at the synapse. A second possibility is that a cytoskeletal molecule that binds $\mathrm{NaChs}$ may become localized at the end plate soon after birth. Third, a basal lamina molecule deposited at the synapse may mediate the aggregation of $\mathrm{NaChs}$. Although one form of agrin did not seem to possess this activity (Lupa and Caldwell, 1991), another form of agrin (Ferns et al., 1992; Ruegg et al., 1992) or some other molecule may provide the $\mathrm{NaCh}$ aggregating activity. Although each of these mecha- 
nisms has been shown to play a role in the clustering of AChRs during synaptogenesis, it is probable that a new set of molecules acts to mediate events in synaptic maturation, including aggregation of $\mathrm{NaChs}$ at the neuromuscular junction.

\section{References}

Almers W, Stanfield PR, Stühmer W (1983) Slow changes in currents through sodium channels in frog muscle membrane. J Physiol (Lond) 339:253-271.

Anderson MJ, Cohen MW (1977) Nerve induced and spontaneous redistribution of acetylcholine receptors on cultured muscle cells. J Physiol (Lond) 268:757-773.

Angaut-Petit D, Molgo' J, Connold AL, Faille L (1987) The levator auris longus muscle of the mouse: a convenient preparation for studies of short-and long-term presynaptic effects of drugs or toxins. Neurosci Lett 82:83-88.

Angelides KJ (1986) Fluorescently labelled $\mathrm{Na}^{+}$channels are localized and immobilized to synapses of innervated muscle fibres. Nature 321: 63-66.

Beam KG, Caldwell JH, Campbell DT (1985) Na channels in skeletal muscle concentrated near the neuromuscular junction. Nature 313 : 588-590.

Bekoff A, Betz WJ (1977) Physiological properties of dissociated muscle fibres obtained from innervated and denervated adult rat muscle. J Physiol (Lond) 271:25-40.

Bctz WJ, Caldwell JH, Kinnamon SC (1984) Increased sodium conductance in the synaptic region of rat skeletal muscle fibers. J Physiol (Lond) 352:189-202.

Betz WJ, Ribchester RR, Ridge RMAP (1990) Competitive mechanisms underlying synapse elimination in the lumbrical muscle of the rat. J Neurobiol 21:1-17.

Bevan S, Steinbach JH (1977) The distribution of $\alpha$-bungarotoxin binding sites on mammalian skeletal muscle developing in vivo. $\mathrm{J}$ Physiol (Lond) 267:195-213.

Bloch RJ (1989) Cell-to-cell interactions during synaptogenesis. Curr Opin Cell Biol 1:940-946.

Boudier J-L, Le Treut T, Jover E (1992) Autoradiographic localization of voltage-dependent sodium channels on the mouse neuromuscular junction using ${ }^{125} \mathrm{I}-\alpha$-scorpion toxin. II. Sodium channel distribution on postsynaptic membranes. J Neurosci 12:454-466.

Brehm P, Kullberg R (1987) Acetylcholine receptor channels on adult mouse skeletal muscle are functionally identical in synaptic and nonsynaptic membrane. Proc Natl Acad Sci USA 84:2550-2554.

Caldwell JH, Milton RL (1988) Sodium channel distribution in normal and denervated rodent and snake skeletal muscle. J Physiol (Lond) 401:145-161.

Caldwell JH, Campbell DT, Beam KG (1986) Na channel distribution in vertebrate skeletal muscle. J Gen Physiol 87:907-932.

Cannon SC, Brown RH Jr, Corey DP (1991) A sodium channel defect in hyperkalemic periodic paralysis: potassium-induced failure of inactivation. Neuron 6:619-626.

Casadei JM, Barchi RL (1987) Monoclonal antibodies against the voltage-sensitive sodium channel from rat skeletal muscle: mapping antibody binding sites. J Ncurochem 48:773-778.

Chiu AY, Sanes JR (1984) Development of basal lamina in synaptic and extrasynaptic portions of embryonic rat muscle. Dev Biol 103: 456-467.

Chomczynski P, Sacchi N (1987) Single-step method of RNA isolation by acid guanidinium thiocyanate-phenol-chloroform extraction. Anal Biochem 162:156-159.

Dahm LM, Landmesser LT (1991) The regulation of synaptogenesis during normal development and following activity blockade. J Neurosci 11:238-255.

Diamond J, Miledi R (1962) A study of foetal and new-born rat muscle fibres. J Physiol (Lond) 162:393-408.

Donahue LM, Schaller K, Sueoka N (1991) Segregation of $\mathrm{Na}^{+}$-channel gene expression during neuronal-glial branching of a rat PNSderived stem cell line, RT4-AC. Dev Biol 147:415-424.

Fallon JR, Gelfman CE (1989) Agrin-related molecules are concentrated at acetylcholine receptor clusters in normal and aneural developing muscle. J Cell Biol 108:1527-1535.

Ferns M, Hoch W, Campanelli JT, Rupp F, Hall ZW, Scheller RH (1992) RNA splicing regulates agrin-mediated acetylcholine receptor clustering activity on cultured myotubes. Neuron 8:1079-1086.
Flucher BE, Daniels MP (1989) Distribution of $\mathrm{Na}^{+}$channels and ankyrin in neuromuscular junctions is complementary to that of acetylcholine receptors and the $43 \mathrm{kD}$ protein. Neuron 3:163-175.

Fontaine B, Sassoon D, Buckingham M, Changeux J-P (1988) Detection of the nicotinic acetylcholine receptor $\alpha$-subunit mRNA by in sith hybridization at neuromuscular junctions of 15-day-old chick striated muscles. EMBO J 7:603-609.

Froehner SC (1991) The submembrane machinery for nicotinic acetylcholine receptor clustering. J Cell Biol 114:1-7.

Goldman D, Staple J (1989) Spatial and temporal expression of acetylcholine receptor RNAs in innervated and denervated rat soleus muscle. Neuron 3:219-228.

Gonoi T, Sherman SJ, Catterall WA (1985) Voltage clamp analysis of tetrodotoxin-sensitive and -insensitive sodium channels in rat muscle cells developing in vitro. J Neurosci 5:2559-2564.

Gonoi T, Hagihara Y, Kobayashi J, Nakamura H, Ohizumi Y (1989) Geographutoxin-sensitive and insensitive sodium currents in mouse skeletal muscle developing in situ. J Physiol (Lond) 414:159-177.

Gu Y, Hall ZW (1988) Immunological evidence for a change in subunits of the acetylcholine receptor in developing and denervated rat muscle. Neuron 1:117-125.

Haimovich B, Schotland DL, Fieles WE, Barchi KL (1987) Localization of sodium channel subtypes in adult rat skeletal muscle using channel-specific monoclonal antibodies. J Neurosci 9:2957-2966.

Kallen RG, Sheng ZH, Yang J, Chen L, Rogart RB, Barchi RL (1990) Primary structure and expression of a sodium channel characteristic of denervated and immature rat skeletal muscle. Neuron 4:233-242.

Kelly AM, Zacks SI (1969) The fine structure of motor endplate morphogenesis. J Cell Biol 42:154-169.

Lupa MT, Caldwell JH (1991) Effect of agrin on the distribution of acetylcholine receptors and sodium channels on adult skeletal muscle fibers in culture. J Cell Biol 115:765-778.

Lupa MT, Hall ZW (1989) Progressive restriction of synaptic vesicle protein to the nerve terminal during development of the neuromuscular junction. J Neurosci 9:3937-3945.

Lupa MT, Krzemien D, Schaller K, Caldwell JH (1991) Expression and distribution of $\mathrm{Na}^{+}$channels in developing rodent skeletal muscle. J Cell Biochem [Suppl] 15C:58(F332).

Magill-Solc C, McMahan UJ (1988) Motor neurons contain agrin-like molecules. J Cell Biol 107:1825-1833.

Massoulie J, Bon S (1982) The molecular forms of cholinesterase and acetylcholinesterase in vertebrates. Annu Rev Neurosci 5:57-106.

Matthews-Bellinger JA, Salpeter MM (1983) Fine structural distribution of acetylcholine receptors at developing mouse neuromuscular junctions. J Neurosci 3:644-657.

Melton DA, Krieg PA, Rebagliati MR, Maniatis T, Zinn K, Green MR (1984) Efficient in vitro synthesis of biologically active RNA and RNA hybridization probes from plasmids containing a bacteriophage SP6 promoter. Nucleic Acids Res 12:7035-7056.

Milton RL, Caldwell JH (1990) Na current in membrane blebs: implications for channel mobility and patch clamp recording. J Neurosci 10:885-893.

Milton RL, Lupa MT, Caldwell JH (1992) Differences in the distribution of $\mathrm{Na}$ channels at neuromuscular junctions of rodent fast-and slow-twitch skeletal muscles. Neurosci Lett 135:41-44.

Mishina M, Takai T, Imoto K, Noda M, Takahashi T, Numa S, Methfessel C, Sakmann B (1986) Molecular distinction between fetal and adult forms of muscle acetylcholine receptor. Nature 321:406-411.

Nitkin RM, Rothschild TC (1990) Agrin-induced reorganization of extracellular matrix components on cultured myotubes: relationship to AChR aggregation. J Cell Biol 111:1161-1170.

Noda M, Ikeda T, Kayano T, Suzuki H, Takeshima H, Kurasaki M, Takahashi H, Numa $S$ (1986) Existence of distinct sodium channel messenger RNAs in rat brain. Nature 320:188-192.

Pappone PA (1980) Voltage-clamp experiments in normal and denervated mammalian skeletal muscle fibres. J Physiol (Lond) 306: $377-410$.

Platt JL, Michael $\Lambda F$ (1983) Retardation of fading and enhancement of intensity of immunofluorescence by $p$-phenylenediamine. $\mathrm{J}$ Histochem Cytochem 31:840-842.

Ravdin P, Axelrod D (1977) Fluorescent tetramethylrhodamine derivatives of $\alpha$-bungarotoxin: preparation, separation, and characterization. Anal Biochem 80:585-592.

Redfern $\mathrm{P}$, Thesleff S (1971) Action potential generation in denervated 
rat skeletal muscle. II. The action of tetrodotoxin. Acta Physiol Scand $82: 70-78$.

Rogart R (1.981) Sodium channels in nerve and muscle membrane. Annu Rev Physiol 43:711-725.

Rogart RB, Cribbs LL, Muglia LK, Kephart DD, Kaiser MW (1989) Molecular cloning of a putative tetrodotoxin-resistant rat heart $\mathrm{Na}^{+}$ channel isoform. Proc Natl Acad Sci USA 86:8170-8174.

Ruegg MA, Tsim KWK, Horton SE, Kröger S, Escher G, Gensch EM, McMahan UJ (1992) The agrin gene codes for a family of basal lamina proteins that differ in function and distribution. Neuron 8:691699.

Ruff RL (1992) Na current density at and away from endplates on rat fast- and slow-twitch skeletal muscle fibers. Am J Physiol 262:C229C234.

Sakmann B, Brenner HR (1978) Change in synaptic channel gating during neuromuscular development. Nature 276:401-402.

Salpeter MM, Loring RH (1985) Nicotinic acetylcholine receptors in vertebrate muscle: properties, distribution and neural control. Prog Neurobiol 25:297-325.

Salpeter MM, Buonanno A, Pinset C, Mulle C, Benoit P, Changeux JP, Chelly I, Gros F, Montarras D, Brehm P, Sheperd D, Froehner SC, Gordon H, Ralston E, Hall ZW, Lupa M, Rotundo R, Bertetta CFV, Gomez AM, Barton F, Randall WR (1992) Regulation of molecules at the neuromuscular junction. In: Neuromuscular development and disease (Kelly AM, Blau HM, eds), pp 251-283. New York: Raven.

Sherman SJ, Catterall WA (1982) Biphasic regulation of development of the high-affinity saxitoxin receptor by innervation in rat skeletal muscle. J Gen Physiol 80:753-768.
Smith MA, Slater CR (1983) Spatial distribution of acetylcholine receptors at developing chick neuromuscular junctions. J Neurocytol 12:993-1005.

Terävainen H (1968) Development of the myoneural junction in the rat. Z Zellforsch Mikrosk Anat 87:249-265.

Thesleff S, Vyskocil F, Ward MR (1974) The action potential in endplate and extrajunctional regions of rat skeletal muscle. Acta Physiol Scand 91:196-202.

Trimmer JS, Cooperman SS, Tomiko SA, Zhou J, Crean SM, Boyle MA, Kallen RG, Sheng Z, Barchi RL, Sigworth FJ, Goodman RH, Agnew WS, Mandel G (1989) Primary structure and functional expression of a mammalian skeletal muscle sodium channel. Neuron $3: 33-49$.

Trimmer JS, Cooperman SS, Agnew WS, Mandel G (1990) Regulation of muscle sodium channel transcripts during development and in response to denervation. Dev Biol 142:360-367.

Vautrin J, Mambrini J (1989) Synaptic current between neuromuscular junction folds. J Theor Biol 140:479-498.

Wallace BG (1989) Agrin-induced specializations contain cytoplasmic, membrane, and extracellular matrix-associated components of the postsynaptic apparatus. J Neurosci 9:1294-1302.

Wallace BG, Qu Z, Huganir RL (1991) Agrin induces phosphorylation of the nicotinic acetylcholine receptor. Neuron 6:869-878.

Weiss RE, Horn R (1986) Functional differences between two classes of sodium channels in developing rat skeletal muscle. Science 233: 361-364. 